\title{
Opportunities and Constraints Facing Fish Production System in DR Congo
}

\author{
Mushagalusa Namegabe Janvier ${ }^{1 *}$, Parent Zihalirwa ${ }^{2}$, Olame Ngangura $^{2}$, Safari Mulume ${ }^{2}$, Léon \\ Nabahungu', Matungulu Kande ${ }^{1}$, Chris Okafor ${ }^{1}$ \\ ${ }^{l}$ International Institute of Tropical Agriculture (IITA) \\ ${ }^{2}$ Universite Evangelique en Afrique (UEA)
}

*Corresponding Author: Mushagalusa Namegabe Janvier, International Institute of Tropical Agriculture (IITA)

\begin{abstract}
The current aquaculture production systems in the village environment and their constraints and opportunities were studied to understand the reasons for the decrease in the number of fishponds in South Kivu, eastern DR Congo. . Little is known about fish production in South Kivu; thus, this study was carried out in two phases: a survey, a follow-up of the farms over the course of a year and a literature review. Accordingly, 305 aquaculturists from three territories were interviewed from May to November 2019. This breeding is mainly practiced by men (91.6\%), adults (45 \pm 14 years), married (93.6\%), fish farmers with no formal education $(36.5 \%$, ) farmers who practice agriculture as their main activity $(68.5 \%$, ) and farmers engaged in fish farming as a secondary activity (60.4\%). Fish farmers have $13 \pm 9$ years' experience; and only 39.0 percent of fish farmers received training on good fish farming practices. Membership to groups or associations is low (6.1\%). Tilapia sp is the widely cultivated species (82.6\%), followed by a combination of Tilapia-Catfish (17.3\%). Fish are reared in medium-sized fishponds $(358.7 \pm 230.4 \mathrm{~m} 2)$ at unknown age $(60.4 \%)$, with a reproduction rate of $(54.7 \pm 37.7$ $\mathrm{kg})$ per growth cycle. The main opportunities in aquaculture in South Kivu are water availability (13.5\% in Kabare, $31.1 \%$ in the Ruzizi plain, and $15.3 \%$ in Walungu), the presence of a fish market, and availability of land suitable for aquaculture (27.1\% in Kabare, $10.9 \%$ in the plain, and $15.3 \%$ in Walungu). On the other hand, the main constraints identified are lack of quality fry (75.5\% in Kabare) and the high cost of labour (60.9\% in the Ruzizi plain and $60.9 \%$ in Walungu).
\end{abstract}

Keywords: Fish farming; constraints; sustainable fish farming; South Kivu.

\section{INTRODUCTION}

Food demand is and will continue to be among the highest around the world and particularly in subSaharan Africa, amidst high growth of agricultural population, which is leading to a decline in land sizes per producer (FAO, 2006). This trend is aggravated by climatic disturbances that lead to the deterioration of production potentials of the available land (APDRA, 2015). There is therefore an urgent need of developing efficient systems. At the global level, Aquaculture is very heterogeneous (Campeas, 2008) of developing efficient sustainable solutions to food security in sub-Saharan Africa. Aquaculture production in sub-Saharan Africa is potential for sustaining growth over the next two decades; hence, there is a need of identifying livestock systems that allow a margin for progress that can increase production significantly. Furthermore, these livestock models must also be sustainable (HELP, 2014b). Fish farming contributes immensely to the improvement of food as it enables other agricultural activities to flourish. The ponds constitute a "pantry," which, during the agricultural season, feeds and rescues a peasant from walking tens of kilometres in search of food (Mbangassi, 1978). In the DR Congo, there was an estimated 78,907 fishponds in 1990 which covered an estimated area of 1,305 ha (Micha, 1974a) with an estimated production of 3,269 tons. In 2000, there was a significant drop in yield and fishponds of up to 2,751 tons and 36,515 fishponds.

In Kivu, fish farming was quite well developed, especially in South Kivu. The number of fishponds was estimated at 1028 over an area of 170 ha with an estimated production of 425tons, mainly from dam ponds (Anonym, 1990). Despite the presence of aquaculture infrastructure in all the provinces in the country, human and material resources are greatly lacking, which includes availability of trained aquaculture managers (FAO, 2005b). Successive Prodepaak country reports (2008-2013) indicate that 
the aquaculture sub-sector in the DR. Congo is currently dominated with small-scale farming, which is mainly based on traditional practices, rudimentary management framework, and lack of improved species among others (Junca, 2009). Small-scale farming, whose production remains insignificant despite the high demand for fish, is particularly predominant in all the provinces, particularly South Kivu (Coche et al., 2005).

The observed slow growth of fish farming in DR. Congo, specifically in the South Kivu province is attributed to among other factors, low use of quality seeds, limited knowledge of best farming and aquaculture practices, problems related to fish feeding practices, diseases, poor extension services and technology dissemination mechanisms, and unfavourable political environment. On the other hand, the benefits and the leading role fish farming could play in strengthening food security of the populations in South Kivu, particularly in rural areas and post-conflict zones, have received little research interest. In 2000, the report of the Provincial Inspection of Agriculture, Fisheries, and Livestock (IPAPEL) by its National Aquaculture Service indicated a decrease of a quarter of fish production in South Kivu. However, the causes for this trend remain unclear. This study therefore aims at renewing the information available on peasant fish farming in South Kivu in the DR Congo, revising fish production policies and proposed strategic orientations for a harmonious and useful development in improving fish farming sector in the DR Congo, especially South Kivu.

\section{Methodology}

\subsection{Presentation of the Study Area}

This study was conducted in the territories of Kabare, Walungu, and the Ruzizi Plain in South Kivu in the eastern part of the Democratic Republic of Congo. The South Kivu province is located at an altitude of $1600 \mathrm{~m} 2^{\circ} 28^{\prime} 21^{\prime \prime}$ from the south latitude and $28^{\circ} 12^{\prime} 25^{\prime \prime}$ from Longitude East. It covers $65,070 \mathrm{~km}^{2}$ with an estimated population of 5 million inhabitants, the majority of whom are farmers. This province has an abundant hydrograph that are favourable for fish farming. The main water systems are rivers, marshes, and perimeters irrigable by rivers. However, it should be noted that the main rivers are two mountain lakes: Lake Kivu at an altitude of 1,470 m and Lake Tanganyika at an altitude of $773 \mathrm{~m}$, which are connected by the Ruzizi River. The climate is tropical of the AW3 type according to Koppen's classification with temperatures ranging from $17^{\circ} \mathrm{C}$ to $20^{\circ} \mathrm{C}$ and an annual rainfall of between $1300 \mathrm{~mm}$ and $1800 \mathrm{~mm}$. In contrast, the Ruzizi plain has a semi-arid climate with an average rainfall of 800 to $950 \mathrm{~mm}$ and 1,000 to $1200 \mathrm{~mm}$ in the mountainous part of the Ruzizi plain and an average annual daily temperature ranging from 26 to $28^{\circ} \mathrm{C}$ (Kasamira 2007).

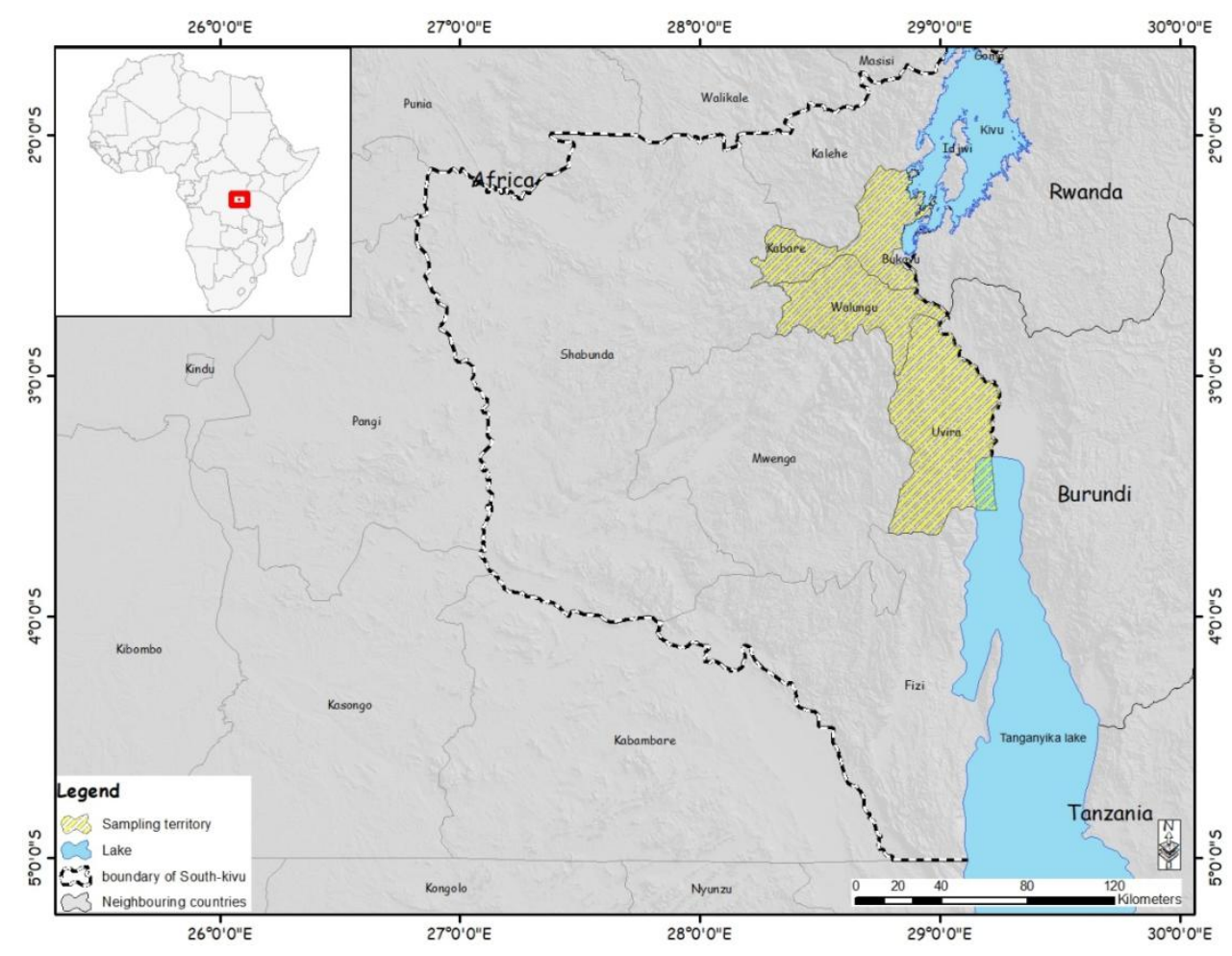

Figure1. Location of the study area 


\subsubsection{Data Collection and Sampling}

Before starting this study, a bibliographical analysis and synthesis of the work on fish farming which were carried out in South Kivu in the DR Congo were made based on the documents collected during the documentary research phase of this study. This was followed by a preliminary field survey of fish farmers in the study area, which was conducted to collect preliminary data and to identify the study area. After this stage, we carried out a survey itself using a questionnaire with questions related to the socio-economic characteristics of the fish farmers, the fish farming systems practiced, the constraints faced by fish farmers and the opportunities available to fish farmers in the study area. The stratified random sampling method was used to survey 300 fish farmers. The different strata were formed according to the size of the fish farmers in the territory of Walungu, Kabare, and the Ruzizi plain. This survey was also supplemented by additional information we obtained through interviews and open-ended interviews with the heads of local development associations, NGOs, and public institutions involved in fish farming.

\subsubsection{Statistical Analysis and Data Processing}

The information collected from fish farmers was first encoded in a matrix in Excel software before being analyzed by $\mathrm{R}$ console 3.5.2 software. Qualitative data were subjected to the chi-square test while quantitative data were subjected to the analysis of variance analysis at $\mathrm{P} \leq . .05$ and the separation of the means were done by the Duncan LSD test based on the smallest significant difference (LSD at $\mathrm{P} \leq 05)$.

\section{RESUltS}

\subsection{Socio-Economic Characteristics of Fish Farmers in South-Kivu}

This section looks at demographic, social, economic characteristics of fish farmers in South-Kivu. Demographic characteristics involved gender of the fish farmers, age, education level, and marital status.

\subsubsection{Demographic Characteristics}

As for gender, our study results show that fish farming is an activity practiced more by men than is by women (Table1). Indeed, men constitute 91.9 percent of fish farmers in the study area as oppose to women that is represented by only 8 percent. The results show further that fish farmers belonged to the age group of between 45-50 years.

Majority of the fish farmers (36.5\%) had not obtained any formal education. This is followed by those who obtained primary education (35.9\%), secondary (20.6\%), and university education (7\%), whose proportion is insignificant.

As for marital status the results show that $93,6 \%$ percent of the respondents are married, $4.4 \%$ are single, and $1.6 \%$ are widows or widowers. The results show further that majority $(88.1 \%)$ of married fish farmers are engaged in fish farmers. This finding implies that fish farming is an activity of married people as opposed to singles. Being married could be a driver that compels married couple to have a stable income of meeting family obligations. Table 1 presents the status of fish farmers and the educational level of fish farmers in different territories.

Table1. Status of Fish Farmers and Educational Level of Fish Farmers in South Kivu $(N=305)$.

\begin{tabular}{|c|c|c|c|c|c|}
\hline & & Kabare & Ruzizi plain & Walungu & \\
\hline \multirow{2}{*}{$\begin{array}{l}\text { Gender of the } \\
\text { fish farmer }\end{array}$} & Female $(\%)$ & 9.7 & 5.0 & 9.4 & \multirow[t]{2}{*}{$\chi^{2}=2.22, p=0.330$} \\
\hline & Male $(\%)$ & 90.3 & 95.0 & 90.6 & \\
\hline \multicolumn{2}{|c|}{ Age of fish farmers (years) } & $44 \pm 12$ & $44 \pm 16$ & $48 \pm 15$ & $F=2.01, p=0.135$ \\
\hline \multirow{4}{*}{$\begin{array}{c}\text { Education level } \\
\text { of the fish } \\
\text { farmer }\end{array}$} & $\begin{array}{c}\text { No formal education } \\
(\%)\end{array}$ & 34.2 & 33.6 & 44.7 & \multirow[t]{4}{*}{$\chi^{2}=9.13, p=0.166$} \\
\hline & Primary $(\%)$ & 31.6 & 41.2 & 36.5 & \\
\hline & Secondary $(\%)$ & 25.8 & 19.3 & 12.9 & \\
\hline & University (\%) & 8.4 & 5.9 & 5.9 & \\
\hline \multirow{4}{*}{$\begin{array}{l}\text { Marital status of } \\
\text { the fish farmer }\end{array}$} & Single $(\%)$ & 3.9 & 5.9 & $3.5 \%$ & \multirow[t]{4}{*}{$\chi^{2}=4.26, p=0.641$} \\
\hline & Divorced (\%) & - & - & 1.2 & \\
\hline & Married (\%) & 94.2 & 92.4 & 94.1 & \\
\hline & Widowed (ve) (\%) & 1.9 & 1.7 & 1.2 & \\
\hline
\end{tabular}




\subsubsection{Social Characteristics of Fish Farmers in South Kivu}

The farmers' participation in training is envisaged to have a positive influence any economic activity farmers are engaged in. It also enables the beneficiaries to acquire knowledge and skills on the management of their farms. In this respect, the results indicate that the majority $(65 \%)$ of fish farmers never had any training on fish farming (Table 2). Only a small proportion (39\%) received training in fish farming. However, it should be noted that access to training on new aquaculture techniques is highly dependent on the environment and membership of a development association (Table 2) at $\mathrm{p}<0.001$. For example, in Kabare majority $(68.4 \%)$ of fish famers received training in fish farming followed by the Ruzizi plain $(22.7 \%)$, and lastly Walungu $(8.2 \%)(\mathrm{p}<0.001)$.

As for membership to farmers' association, the majority (93.9\%) of fish farmers do not belong to any associations. The territories where fish farmers belong to farmers association include Kabare (11\%), followed by Ruzizi plain (3.4\%) and lastly Walungu (1.2\%). In our study, the survey results showed that most fish farmers in South Kivu have an average experience of 13 years in the aquaculture sector. However, experience in the aquaculture sector is not influencing factor in successful fish farming in the study area $(\mathrm{p}=0.458)$ The results relating to the level of supervision of fish farmers are presented in Table2

Table2. Level of supervision of fish farmers and main activities of fish farmers in South Kivu

\begin{tabular}{|c|c|c|c|c|c|}
\hline \multirow{2}{*}{\multicolumn{2}{|c|}{$\begin{array}{l}\text { Participation in training on fish } \\
\text { farming }\end{array}$}} & \multirow{2}{*}{$\begin{array}{c}\text { Kabare } \\
68.4 \% \\
\end{array}$} & \multirow{2}{*}{$\begin{array}{c}\text { Plaine de la Ruzizi } \\
22.7 \%\end{array}$} & \multirow{2}{*}{$\begin{array}{c}\text { Walungu } \\
8.2 \%\end{array}$} & \multirow{2}{*}{$\begin{array}{c}\chi^{2}=103.39 \\
p<0.001\end{array}$} \\
\hline & & & & & \\
\hline \multirow{2}{*}{$\begin{array}{l}\text { Membership to } \\
\text { fish farming } \\
\text { group }\end{array}$} & Group & $11.0 \%$ & $3.4 \%$ & $1.2 \%$ & \multirow{2}{*}{$\begin{aligned} \chi^{2} & =11.52, \\
p & =0.003\end{aligned}$} \\
\hline & Individual & $89.0 \%$ & $96.6 \%$ & $98.8 \%$ & \\
\hline \multicolumn{2}{|c|}{ Experience in Aquaculture (years) } & $12 \pm 9$ & $14 \pm 7$ & $13 \pm 11$ & $\begin{array}{c}F=0.78 \\
p=0.458\end{array}$ \\
\hline \multicolumn{2}{|c|}{ Access to loan } & $9.7 \%$ & $14.3 \%$ & $15.3 \%$ & $\begin{array}{c}\chi^{2}=48.73, \\
p<0.001\end{array}$ \\
\hline
\end{tabular}

Table3. Main activities of the respondent fish farmers in South Kivu $(n=305)$

\begin{tabular}{|c|c|c|c|c|c|}
\hline & & Kabare & $\begin{array}{c}\text { Plaine de la } \\
\text { Ruzizi }\end{array}$ & Walungu & \\
\hline \multirow{7}{*}{$\begin{array}{l}\text { Main } \\
\text { activity of } \\
\text { the fish } \\
\text { farmer }\end{array}$} & Artist (\%) & 1,9 & - & 2,4 & \multirow{7}{*}{$\begin{array}{c}\chi^{2}=48.73 \\
p<0.001\end{array}$} \\
\hline & Livestock (\%) & 2,6 & - & 2,4 & \\
\hline & Salaried employment & 36,8 & 9,2 & 10,6 & \\
\hline & Crop production $(\%)$ & 54,2 & 81,5 & 76,5 & \\
\hline & Small business $(\%)$ & 1,3 & 1,7 & 3,5 & \\
\hline & Fish farming (\%) & 1,9 & 3,4 & 1,2 & \\
\hline & Technician (\%) & 1,3 & 4,2 & 3,5 & \\
\hline \multirow{7}{*}{$\begin{array}{c}\text { Secondary } \\
\text { occupation } \\
\text { of the fish } \\
\text { farmer }\end{array}$} & Artist (\%) & - & 0,8 & 3,5 & \multirow{7}{*}{$\begin{array}{c}\chi^{2}=54.22, \\
p<0.001\end{array}$} \\
\hline & None $(\%)$ & 1,3 & 5,0 & 1,2 & \\
\hline & Livestock $(\%)$ & 9,0 & 21,8 & 31,8 & \\
\hline & $\begin{array}{c}\text { Salaried employment } \\
(\%)\end{array}$ & - & - & 1,2 & \\
\hline & Crop production $(\%)$ & 12,9 & 5,0 & 11,8 & \\
\hline & Small business $(\%)$ & 2,6 & 9,2 & 11,8 & \\
\hline & Fish farming (\%) & 74,2 & 58,0 & 38,8 & \\
\hline
\end{tabular}

After looking at the level of training and the level of supervision of fish farmers through membership in a development association, we focused on the respondents' economic activities, which were divided into main and secondary activities. However, it should be noted that agriculture is the main economic activity, employing majority $(68.5 \%)$ of fish farmers surveyed. This is followed by nonfarm employment employing (21.4\%), followed by fish farming, handcraft, and DIY. In South Kivu, only 2.2 percent of the respondents are involved in fish farming, after crop production, which is carried out by 68.5 percent of the respondents. Therefore, fish farming is considered as secondary after crop production in terms of economic importance. 


\subsubsection{Economic Characteristics of Fish Farmers in South Kivu}

Access to fish credit seems limited and almost non-existent in South Kivu ( $\mathrm{p}=0.387)$. Aquaculture in South Kivu uses different types of labour ( $\mathrm{p}<0.001)$. In Walungu and in the Ruzizi Plain 88.2 and 75.6 percent of the manpower respectively comprise family labour, which is less and less reliable as more and more young people continue with schooling and some get into temporary or permanent emigration. In Kabare, 82.6 percent of the workforce comprises hired labour force. However, 5 percent are organized around community aquaculture to ensure security or an increase of monetary income to enable farmers to meet certain investments or family needs. Aquaculture in South Kivu has been facing many problems over the last few decades. These include deterioration of the means of production (impoverishment of the soil, obsolete fish farming equipment, low use of inputs, food of dubious quality or of poor quality, and the like), irregular rainfall, all of which resulting in low fish productivity and a growing lack of interest in aquaculture among young people.

Table 4 presents the economic characteristics of fish ponds in South Kivu, including access to fish credit and the type of labour used in fish farm $(n=305)$.

Table4. Economic characteristics of fishponds in South Kivu

\begin{tabular}{|c|c|c|c|c|c|}
\hline & & Kabare & $\begin{array}{l}\text { Plaine de } \\
\text { la Ruzizi }\end{array}$ & Walungu & \\
\hline \multirow{3}{*}{$\begin{array}{c}\text { Type of labour } \\
\text { used }\end{array}$} & Wage labour force & $82.6 \%$ & $63.0 \%$ & $36.5 \%$ & $\begin{array}{c}\chi^{2}=51.79, \\
p<0.001\end{array}$ \\
\hline & Family labour force & $57.4 \%$ & $75.6 \%$ & $88.2 \%$ & $\begin{aligned} \chi^{2} & =27.24, \\
p & <0.001\end{aligned}$ \\
\hline & Community-based & $3.2 \%$ & $7.6 \%$ & $4.7 \%$ & $\begin{array}{l}\chi^{2}=2.68 \\
p=0.262\end{array}$ \\
\hline \multirow{4}{*}{$\begin{array}{l}\text { Assessment of } \\
\text { profitability }\end{array}$} & Low & $15,6 \%$ & $3,4 \%$ & $29,8 \%$ & \multirow{4}{*}{$\begin{array}{c}\chi^{2}=78.92, \\
p<0.001\end{array}$} \\
\hline & Average & $14,8 \%$ & $28,1 \%$ & $45,2 \%$ & \\
\hline & High & $24,4 \%$ & $30,1 \%$ & $16,3 \%$ & \\
\hline & Very high & $45,2 \%$ & $38,4 \%$ & $8,7 \%$ & \\
\hline
\end{tabular}

\subsection{Characteristics of Fish Ponds in South Kivu}

Two fish species namely clariasspp and Tilapia spp are reared in the ponds in South Kivu. These results are in line with those obtained by Mbouombouo (2007) in Santchou. However, Tilapia spp. is the highest species but this depends on the area $(\mathrm{p}<0.001)$.

The availability and dietary requirements of fish species and land fertility are some of the factors that determine what type of species to be farmed by farmers. Other factors include adaptive capacity of each species to the environmental conditions, as some of the fish species are increasingly sensitive to climatic hazards.

Indeed, farmers cultivate fish either in association or in monoculture depending on the area of production $(\mathrm{p}<0.001)$. In monoculture, only Tilapia is cultivated, whereas in association Catfish is often cultivated with Tilapia. Cultivation in association is mainly practised in the Ruzizi Plain (29.2\%), followed by Walungu (11\%), and lastly in Kabare (5.9\%). This trend can be attributed to the fact that households do not associate food and/or cash crops and marketing of the species.

Majority of fish farmers do not have knowledge on the age of fishponds and this trend varies from area to area $(\mathrm{p}<0.001)$. Lack of knowledge of the age of their ponds is more severe among fish farmers in the Ruzizi plain, as opposed to fish farmers in Walungu and Kabare territories. The ponds in South Kivu are on average 13 years old, with varying sizes $(\mathrm{p}<0.001$. The average surface area of fishponds is $358.7 \pm 230.4 \mathrm{~m} 2$.

As for the number of man-days, the results show variation according to zones $(\mathrm{p}=0.051)$. Fish farmers in the Ruzizi Plain use more man-hours than do fish farmers in Walungu and Kabare. This would be attributed to availability of manpower as well as economic resources among fish farmers. The quantity of fish produced per harvest varies from one area to another $(\mathrm{p}<0.001)$. Fish farmers in Kabare produce more fish than do fish farmers in the Ruzizi plain and Walungu. 
Table5.

\begin{tabular}{|c|c|c|c|c|c|}
\hline & Kabare & $\begin{array}{c}\text { Plaine de la } \\
\text { Ruzizi }\end{array}$ & Walungu & \\
\hline \multirow[t]{2}{*}{ Fish species } & Catfish-Tilapia & $5,9 \%$ & $29,2 \%$ & $11,0 \%$ & \multirow[t]{2}{*}{$\chi^{2}=34.97, p<0.001$} \\
\hline & Tilapia & $94,1 \%$ & $70,8 \%$ & $89,0 \%$ & \\
\hline \multirow{2}{*}{$\begin{array}{l}\text { Ponds Age } \\
\text { (Years) }\end{array}$} & Inconnu & $49,0 \%$ & $74,8 \%$ & $61,2 \%$ & $\chi^{2}=18.71, p<0.001$ \\
\hline & Connu & $13 \pm 9$ & $16 \pm 6$ & $13 \pm 8$ & $F=1.60, p=0.205$ \\
\hline \multicolumn{2}{|c|}{ Ponds size $\left(\mathrm{m}^{2}\right)$} & $335,5 \pm 253,8$ & $489,8 \pm 214,4$ & $132,3 \pm 98,1$ & $F=22.28, p<0.001$ \\
\hline \multicolumn{2}{|c|}{ Number of labour } & $4 \pm 3^{b}$ & $6 \pm 5^{\mathrm{a}}$ & $5 \pm 5^{\mathrm{ab}}$ & $F=1.26, p=0.051$ \\
\hline \multirow[t]{2}{*}{ Type of pond } & Dam & $16,1 \%$ & 11,5 & $16,2 \%$ & \multirow{2}{*}{$\begin{array}{l}F=2.62 \\
p=0.269\end{array}$} \\
\hline & Derivation & $83,9 \%$ & $88,5 \%$ & $83,8 \%$ & \\
\hline \multirow{8}{*}{$\begin{array}{l}\text { Elements } \\
\text { used in the } \\
\text { feeding of } \\
\text { poisons }\end{array}$} & None & $0,6 \%$ & $0,4 \%$ & $2,1 \%$ & \multirow[t]{8}{*}{$\chi^{2}=52.45, p<0.001$} \\
\hline & Dung & $5,5 \%$ & $4,6 \%$ & $3,1 \%$ & \\
\hline & $\begin{array}{l}\text { Waste and } \\
\text { Peelings }\end{array}$ & $3,2 \%$ & $2,8 \%$ & $3,1 \%$ & \\
\hline & Dregs & $5,5 \%$ & $7,0 \%$ & $2,8 \%$ & \\
\hline & $\begin{array}{c}\text { Leaves, Herbs } \\
\text { and Fruits }\end{array}$ & $42,4 \%$ & $31,0 \%$ & $54,4 \%$ & \\
\hline & $\begin{array}{l}\text { Slaughterhouse } \\
\text { residues, Ash, } \\
\text { Wood stain, } \\
\text { Bran, Oilcake } \\
\text { and Flour }\end{array}$ & $4,9 \%$ & $3,5 \%$ & $0,3 \%$ & \\
\hline & Harvest residues & $28,5 \%$ & $35,9 \%$ & $25,4 \%$ & \\
\hline & Household waste & $9,4 \%$ & $14,8 \%$ & $8,7 \%$ & \\
\hline \multicolumn{2}{|c|}{ Fish harvested last season $(\mathrm{Kg})$} & $80 \pm 43,5^{\mathrm{a}}$ & $56,3 \pm 31,8^{\mathrm{ab}}$ & $31,3 \pm 22,3$ & $F=39.43, p<0.001$ \\
\hline
\end{tabular}

South Kivu's fishponds are moderately appreciated for their productivity, but there is a significant difference between the different areas $(\mathrm{p}<0.001)$. Table 6 presents fish farmers' assessment on the productivity of fishponds in South Kivu $(n=305)$.

Table6. Farmers' perception of fishpond productivity

\begin{tabular}{|l|l|l|l|l|}
\hline & Kabare & Plain de la Ruzizi & Walungu & \\
\hline Extremely poor & $15.0 \%$ & $10.7 \%$ & $16.7 \%$ & \multirow{2}{*}{$\begin{array}{l}\chi^{2}=18.61, \\
p<0.001\end{array}$} \\
\hline Poor & $29.9 \%$ & $21.4 \%$ & $22.6 \%$ & \\
\cline { 1 - 3 } Moderately good & $29.9 \%$ & $36.6 \%$ & $31.0 \%$ & \\
\hline
\end{tabular}

\subsection{Purposes for Fish Production}

It can be seen that in South Kivu, fish farming is mainly carried out for home consumption to meet the demand of animal protein in household, but the nature of consumption varies from one area or territory to another. Apart from home-consumption, fish is produced for sale to meet financial needs of the household such as paying for school fees for children and meeting expenses for clothing and other basic needs. Table 7 shows the average annual income of fish farmers in South Kivu.

Table7. Average income from fish farming in South Kivu

\begin{tabular}{|c|c|c|c|c|c|}
\hline \multicolumn{2}{|c|}{} & Kabare & $\begin{array}{c}\text { Plain de la } \\
\text { Ruzizi }\end{array}$ & Walungu & Total \\
\hline \multirow{2}{*}{ Averageincome } & $\begin{array}{c}\text { Own } \\
\text { consumption }\end{array}$ & $24.4 \%$ & $11.1 \%$ & $43.3 \%$ & $24.4 \%$ \\
\cline { 2 - 6 } & Known & $3164.4 \pm 2255.9^{\mathrm{a}}$ & $2573.6 \pm 1688.9^{\mathrm{ab}}$ & $1889.3 \pm 1636.5^{\mathrm{b}}$ & $2641.9 \pm 2240.8$ \\
\hline
\end{tabular}

Perception of the constraints related to fish production in the Eastern DR Congo in the South Kivu Province.

Table8. Constraints related to fish production in eastern DRC

\begin{tabular}{|c|c|c|c|c|c|c|}
\hline \multirow[t]{2}{*}{ Constraints } & \multicolumn{2}{|c|}{ Kabare } & \multicolumn{2}{|c|}{ Walungu } & \multicolumn{2}{|c|}{ Plaine Ruzizi } \\
\hline & Sever & Rank & Sever & Rank & Sever & Rank \\
\hline \multicolumn{7}{|c|}{ Fish production constraints } \\
\hline Lack of quality seed & $75.5 \%$ & I & $48.1 \%$ & IV & $65.9 \%$ & III \\
\hline
\end{tabular}




\begin{tabular}{|c|c|c|c|c|c|c|}
\hline \multicolumn{5}{|c|}{} & \multicolumn{5}{l|}{} \\
\hline Lack of quality fish feed & $52.2 \%$ & II & $42.6 \%$ & V & $52.7 \%$ & VI \\
\hline Lack of technical knowledge & $51.7 \%$ & III & $57.3 \%$ & II & $61.2 \%$ & IV \\
\hline Lack of equipment & $42.9 \%$ & IV & $49.8 \%$ & III & $68.4 \%$ & II \\
\hline Absence of extension service & $38.3 \%$ & V & & & & \\
\hline Lack of capital & $30.4 \%$ & VI & & & & \\
\hline High labour costs & & & $60.9 \%$ & I & $77.7 \%$ & I \\
\hline The presence of pests (snakes, birds, toads) & & & $40.1 \%$ & VI & $46.9 \%$ & VII \\
\hline Poor access and security of land & & & $35.7 \%$ & VII & & \\
\hline Difficulties related to transportation & & & & & $56.2 \%$ & V \\
\hline
\end{tabular}

The cost of labour is among the leading constraints facing fish production. This is followed by lack of quality animal feed, which is the second most important constraint of fish production in South Kivu; and it is the third and fourth constraints related to fish production in Kabare and in the Ruzizi plain respectively. Specifically, good quality animal feeds are not available in time; this is the second most serious constraint in Kabare (gravity 52.2\%). In addition, lack of technical knowledge is a major constraint to fish production in the South Kivu and in the DRC generally. Lack of technical knowhow is classified as the second and third constraints affecting production in Kabare and Walungu respectively. Farm tools (machetes, hoes, rakes, wheelbarrows, and the like) are not available and this constitutes the fourth major constraint in Kabare (gravity 42.9\%), third in Walungu (gravity 49.8\%), and second serious constraint in the Ruzizi Plain (gravity 68.4\%). Lack of fish extension services (severity 38.3\%) and lack of sufficient capital for fish farming activity (severity 30.4\%) were reported as constraints only in Kabare; and were ranked as fifth and sixth serious constraint respectively.

\subsection{Fish Farming Opportunities in South Kivu}

Table9.

\begin{tabular}{|c|c|c|c|c|}
\hline & Kabare & Ruzizi plains & Walungu & \\
\hline $\begin{array}{l}\text { Access to fish ponds for fish } \\
\text { farming }\end{array}$ & $11,6 \%$ & $13,4 \%$ & $16,5 \%$ & \multirow[t]{6}{*}{$\begin{aligned} \chi^{2} & =24.94 \\
p & =0.005\end{aligned}$} \\
\hline $\begin{array}{c}\text { Capacity for intensification and } \\
\text { extension of fish farming }\end{array}$ & $27,1 \%$ & $10,9 \%$ & $15,3 \%$ & \\
\hline $\begin{array}{l}\text { Availability of water (water } \\
\text { bodies) suitable for aquaculture }\end{array}$ & $13,5 \%$ & $31,1 \%$ & $15,3 \%$ & \\
\hline $\begin{array}{l}\text { Availability of suitable areas } \\
\text { for fish farming }\end{array}$ & $18,1 \%$ & $16,0 \%$ & $16,5 \%$ & \\
\hline $\begin{array}{c}\text { Diversity of species suitable for } \\
\text { aquaculture farming }\end{array}$ & $15,5 \%$ & $12,6 \%$ & $15,3 \%$ & \\
\hline $\begin{array}{l}\text { Presence of fish markets and } \\
\text { fish inputs }\end{array}$ & $14,2 \%$ & $16,0 \%$ & $21,2 \%$ & \\
\hline
\end{tabular}

However, the fish farming in South Kivu provides many livelihood opportunities ( $\mathrm{p}=0.005$ ): its multi functionality in economic, social, and environmental terms is still little known (insufficient quantified indicators). Therefore, full potential of fish farming in South Kivu has not been fully exploited. These potentials include favourable conditions for intensifying and expanding fish farming, linked to the land pressure, multi-activity of fish farmers, the density of fish farming services, accessibility of fishponds for fish farming, and finally the spatial concentration of fish and agricultural activities that promote complementarities.

The presence of fish markets and fish inputs reduces transport costs as opposed to lack of fish markets as is the case in rural areas. Indeed, the former requires less energy and little time to transport the products, especially fish products to the consumers (transport, storage). This improved energy productivity of fish farming in the marketing of the products leading to a reduction in environmental pollution linked to fossil energy consumption. Other considerations should such as the reduction in post-harvest losses due to the proximity of production areas or a better quality of the products in terms of freshness should also be taken into account. 


\section{DISCUSSION}

\subsection{Socio-Economic Characteristics of Fish Farmers in South Kivu}

Women are less interested or responsible for managing a fishpond within the household. Low representation of women as opposed to men in fish farming and in pond management is attributed to the reason that pond maintenance and development work requires a lot of effort. Women do not have easy access to credit or land as is the case with men to be able to acquire and maintain a fishpond. These results are consistent with the results observed by Dossou (2008) in Benin. Another study conducted in the forest zone in Cameroon also revealed that only five percent of fishponds were owned by women; and that the few women who owned fishponds were assisted by their husbands in the management and maintenance, as is the case in our study area (Hirigoyen et al. 1997, FAO, 1993). In trying to link the productivity of fishpond by gender within the household and cultural aspects in the community, it should also be noted that fish farming, like any activity when it is profitable, tends to be taken over by men at the expense of women. It therefore seems that in our study area, fish farming being a profitable enterprise, is managed by men. These appropriate its benefits instead of women who constitute supplementary workforce to men. Similar results were reported by Mirindi (2018) in irrigated fish farms in the Ruzizi plain.

The results obtained from our study in relation to age and education level are in line with the results of studies conducted by FAO (1993) in Madagascar, which showed that the average age of fish farmers varied from 40 to 50 years. We believe that the high proportion of adults in fish farming as opposed to young people is attributed to the reason that at this age, people have huge responsibilities of taking care of the household and ensuring its survival.

Aquaculture technology requires particular technical knowledge in its application, the level of education of fish farmers is generally recognized as a criterion favouring aquaculture innovation (Abdulai and Huffa, 2005; Barham et al., 2004; Foltz and Chang, 2002; Sauer and Zilberman, 2009). In our study, majority of fish farmers have a low level of education. We believe that this could be a barrier against the adoption of new technologies. This therefore calls for developers and researchers into making sufficient efforts in training and awareness raising among fish farmers.

The wide dispersion of accessibility of fish farming training can be explained in part by the presence of organizations working in the aquaculture sector in the various study areas on the one hand and on the other hand, the interest, long experience of farmers in fish farming, and the dynamism of development associations (Ntsama and Kamgnia, 2008). Observations made in the field show, for example, that in Kabare there are more organizations working in aquaculture than there are in the Ruzizi Plain and Walungu. It should also be noted that the centre for breeding and research and the introduction of fish farming was set up in Nyakabere in Kabare by MrVanot during the colonial times. This motivated the local population in the study area into developing interest in fish farming leading to improving their food security. Membership to farmers' association also influences the level of adoption of new aquaculture practices in the study area. Since, members of the associations are the primary beneficiaries to things such as training or aquaculture extension services.

Low membership to farmers' associations demonstrates further as to why fish farmers do not have access to training from state services and organizations, which could influence the success of fish farming as suggested by Alpha and Castellanet (2007). As observed by Gedikoglu (2013), membership to cooperation or association among fish farmers makes it easy for them to acquire information and experience that reduces uncertainty and thus allows fish farmers to perceive innovation and the risks involved in a more objective way (Parcell and Gedikoglu (2013). Experience and/or seniority in the field are essential and important factor successful fish farming.

\subsection{Farmers' Experience}

Fish farming has been in existence since colonial times. However, with the departure of Belgian, Chinese and American cooperation support following the many wars in the East of the country, many fish farmers abandoned fish farming. However, with the resumption of cooperation and NGOs, fish farming has begun to resume gradually. Lack of experience on the part of current fish farmers could have a negative impact on production because, according to FAO (2015), the revival and further expansion of commercial aquaculture development is limited by lack inexperience among fish farmers in the field. Other limiting factors include lack of basic technical skills for the private sector 
workforce and insufficient extension services in terms of effective technical support, among others. Fish farming and livestock farming in general strengthen household income and ensure that household survives and children go to school. The high proportion of farmers engaged in agriculture in relation to other activities is explained by the fact that agriculture is the main source of household income and is a source of the main inputs used by farmers to feed both fish and livestock.

Indeed, crop production is an important source of inputs to aquaculture (food, fertilization, ploughing tools, etc.), and contributes to household food satisfaction through the home-consumption of fish. Aquaculture also allows the capitalization (hoarding) of the financial benefits of the family farm to be easily mobilized if necessary. These two activities (crop production and fish farming) constitute the main economic activities of the households, and these activities supplement employment and trade. However, due to an increasingly precarious socio-economic environment, fish farming households have adopted new non-agricultural activities to sustain their livelihoods.

This diversity of activities shows the need of securing family income and of promoting financial independence and security. In addition, since the study area is a mountainous, it is in the interest of the inhabitants to take advantage of this opportunity to engage in diverse economic activities, this is why crop production is the main activity of fish farmers.

\subsection{Economic Characteristics of Fish Farmers in South Kivu}

The study results indicated that there is a great variability of sizes of fishponds in study areas. Indeed, on average, ponds in the Ruzizi plain are very larger than the ponds in Kabare and Walungu. Their common point is their reduced surfaces of between $128.3 \mathrm{~m} 2$ and $589.1 \mathrm{~m} 2 \ldots$ This would be due to lack of manpower because fish farming is essentially a family business. These results are consistent with the results obtained by other researcher (see for example, Chikou, 2006; FAO, 1993; Rossou, 2008; Toko et al., 2011). According to Dossou (2008), the surface area of ponds depends on the means available to farmers; rich people or farmer fishing groups have the prerogative of keeping large surface areas of ponds. According to Satia (1989 cited by Lazard et al., (1991), small fish farms are widely practised and account for more than 95 percent of the ponds in operation in tropical Africa. As observed by Hauber et al (2011), the predominance of small pond areas among a large number of stakeholders reflects an acceptance of the practice among the local population. Fish production remains less and less appreciated due to the multiple constraints recorded in fish farming. As FAO (2015) shows, in order to increase fish production and consumption, governments in these countries should commit themselves in developing aquaculture systems with the potential of becoming economically viable. This includes the construction of canals, recycling tanks, nurseries, and forming of aquaculture/fish farming associations and/or livestock farming. In addition, the renaissance and expansion of aquaculture development are limited by lack of a policy framework, lack of basic technical skills for the private sector workforce, and insufficient information and equipment from extension services on effective technical support. Others include poor seed and distribution mechanisms, insufficient fish feed due to, in part, lack of incentives for its production, limited access to land and information, inadequate support infrastructure and institutional arrangements.

\subsection{Constraints Related to Fish Production in South Kivu Province}

The results presented here are similar to those obtained by Inyang, (2007) in Akwa Ibom State in Nigeria. Development of quality seeds and the establishment of fishponds would make it possible to create new ecological niches for fish (FAO, 2010a). To remedy this situation, Edwards (2000) advocated for strong private sector involvement in the supply of quality seed with emphasis on decentralized production.

As Anonymous (1996) argues, fish yield is largely determined by the level of diet. In addition, aquaculture feed is composed of many ingredients that are mixed in varying proportions to complement each other to form a nutritionally complete compound diet. According to FAO (2010c), such feeds are manufactured in industrial feed grinding facilities and are distributed and sold using conventional market chains. These facilities should therefore be set up. FAO (2001) observes further that nutritionally adequate fish feed is fortified by a specific formula to be fed as a single ration capable of maintaining life and/or promoting production, with no additional substances added except water. 
This would be explained by farmers' misunderstanding of the biology of the fish selected for production. Fish farmers have a false impression that, as in artisanal fisheries where fish populations are self-sufficient, an aquaculture investor only needs to supply a pond and leave it for a given period of time, after which it can be exploited. They do not know that the stocked ponds had to be well managed and the fish well fed to ensure abundant harvest. This requires good knowledge of fish biology. For example, FAO (2010b) shows that, there are the best aquaculture management practices that aim at improving the quantity, safety, and quality of products taking into account animal health and welfare, food safety, environmental and socio-economic sustainability and that these aquaculture management practices are carried out voluntarily. As SARNISSA (2001) shows, training and education must be better oriented to specific needs; producer organizations, NGOs, and that training centres should play an important role in the provision of training and education.

\section{CONClusion}

Despite its low productivity due to environmental and management hazards, fish farming plays a significant role in the socio-economics of people in South Kivu Province in the Democratic Republic of Congo. In this area, the responsibility and liability in fish farming lie with men, who are married and have no formal education. Congolese fish farming in South Kivu is very rudimentary, since it is considered a secondary activity and because livestock farmers lack knowledge and skills in good aquaculture practice in South Kivu

Fish farming is not carried out by well-trained actors, this leads to significant and sometimes total losses of fish produce. Many fish farmers do not belong to farmers' associations, which would have increased profitability of their fish farming activities and development of the fish farming value chain. Basic knowledge in good management practice, supervision of livestock farmers through regular monitoring together with prophylactic measures (diagnosis, prevention, treatment, and eradication of diseases) provided by the public authorities would be instrumental in improving fish production and productivity and thereby improving the living conditions of fish farmers in South Kivu province.

\section{REFERENCES}

[1] Abdulai A., Huffman W.E. 2005. The diffusion of new agricultural technologies: The case of crossbredcow technology in Tanzania. American Journal of Agricultural Economics, 87(3): 645-659.

[2] Adegbola P. Y, Adekambi, 2008. Adaption et impact socio-économique de la semi-mécanisation du procédé de transformation des amandes de karite en beurre au nord-Benin.

[3] ANAPI, 2017. Fiche technique pêche et élevage,

[4] APDRA, 2015. Pisciculture paysanne (Rapport d'activité). L'innovation piscicole pour satisfaire les besoins alimentaires.

[5] Arnaud C., 2008. Modélisation de l'hétérogénéité de croissance dans le système aquacole. Sciences agricoles. Institut National Polytechnique de Lorraine, 2008. Français. <NNT : 2008INPL011N>.<tel01753046>

[6] Chikou A., 2006. Etude de la démographie et de l'exploitation halieutique de six espèces de poissons-chats (Teleostei, Siluriformes) dans le delta de l'Ouémé au Bénin. Thèse de Docteur en Sciences biologiques (Zoologie). LDPH/FACULTE DES SCIENCES, Université de Liège

[7] COCHE A., et Urbain F. 2005. Global aquaculture production in Dem. Rep. of the Congo. Rome: FAO, 2005.

[8] Dossou, S. 2008. Études des potentialités et des contraintes de développement de la pisciculture dans la commune de Malanville au Bénin. Thèse d'Ingénieur Agronome. Faculté des Sciences Agronomiques, Université d'Abomey-calavi. Bénin 83p

[9] FAO, 2005a. Global aquaculture production (1950-2004) Congo, Dem. Rep. of the.

[10] FAO, 2005b. Database on introductions of aquatic species (DIAS). Search for Introduced Species Fact Sheet - Congo, Dem. Rep. of the.

[11] FAO, 2006. Sécurité alimentaire et développement agricole en Afrique subsaharienne. Rapport principal, Rome.

[12] FAO, 2007. La situation mondiale des pêches et de l'aquaculture. ISSN 1020-5497, Rome, Département des pêches et de l'aquaculture.

[13] FAO, 2015. Séminaire: expérience africaine en matière d'aquaculture commerciale et d'implication des communautés dans la gestion des pêches

[14] FAO, 2019a. Technologies liées à l'aquaculture, e-Bulletin, FIGIS 
[15] FAO, 2019b. Vue générale du secteur aquacole national (1960-2005)Congo, Dem. Rep. of the

[16] FAO,. 2014a. The State of World Fisheries and Aquaculture 2014. Rome. 223 p.

[17] FAO. 1993. Etude de l'impact quantitatif des activités rizipiscicoles et piscicoles dans les régions pilotes du Vakinankaratra et du Betsileo, campagne 1991-1992. Projects reports $\mathrm{N}^{\circ}$ 9.Madagascar. 72p

[18] FAO. 2014. Securing sustainable small-scale fisheries: update on the development of the Voluntary Guidelines for Securing Sustainable Small-Scale Fisheries in the Context of Food Security and Poverty Eradication(SSFGuidelines).COFI/2014/3(http://www.fao.org/cofi/231500423411126421a3feb059f7c1a6e 5e92c.pdf

[19] Hauber M. E., Von V. 2011. Description and improvement of the 'Whedo"-AquacultureSystem in Malanville (North of Benin) 204p

[20] HELP, 2014b. Groupe d'experts de haut niveau, 2014. La durabilité de la pêche et de l'aquaculture au service de la sécurité alimentaire et de la nutrition. Rapport du Groupe d'experts de haut niveau sur la sécurité alimentaire et la nutrition du Comité de la sécurité alimentaire mondiale, Rome 2014.

[21] Hirigoyen J. P., Manjeli Y., Mouncharou G. C. 1997. Caractéristiques de la pisciculture dans la zone forestière au centre Cameroun. Tropicultura. $6 \mathrm{p}$

[22] Junca D., 2009. Vue général du secteur des pêches national. Rome: FAO, 2009. KESTEMONT, Peter. Fish feed technology. Rome: FAO, 1980.

[23] Kevin, 2008 .Discharge and Other Hydraulic Measurements for Characterizing the Hydraulics of Lower Congo River, July 2008 U.S. Geological Survey.

[24] Kpadonou R. A. B, Adégbola P. Y. \&Tovignan S. D. 2011. Climate change Symposium sur le changement climatique: Innovations paysannes d'adaptation à la vulnérabilité climatique dans la basse vallée de l'Ouémé ln www.adaptation2011.net

[25] Lazard J.; Lecornoe Y.; Stornal B.; Weigel J-Y., 1991. Pisciculture en Afrique Subsaharienne: Situations et projets dans des pays francophones, propositions d'action Rapport d'étude, Ministère de la coopération et du développement Coopération Française, CTFT,

[26] Marra, M., Pannell, D. J., Abadi Ghadim, A. 2003. The economics of risk, uncertainty and learning in the adoption of new agricultural technologies: where are we on the learning curve? Agricultural Systems, 75(2-3): 215-234.

[27] Mbouombouo D., 2007, Caractérisation des étangs d'inondation de la plaine des Mbô et analyse des facteurs influençant leur production piscicole, Mémoire de fin d'études présenté en vue de l'obtention du diplôme d'Ingénieur des Eaux, Forêts et Chasses, Université de Dschang, FASA-Diplôme d'Ingénieur des Eaux, Forêt et Chasses, 2007

[28] NtsamaEtoundi S.M. et Kamgnia D.B. 2008. Les déterminants de l'adoption des variétés améliorées de maïs : adoption et impact de la «CMS 8704 ». Université de Yaoundé II Soa. 23 p.

[29] Sauer, J., Zilberman, D. 2009. Innovation behaviour at farm level-Selection and identification. 49th annual meeting of the German. Association of Agricultural Economics and Sociology, GEWISOLA, Kiel, $26 \mathrm{p}$.

[30] Toko 1. L, Attakpa E. Y., Baco M. N., Gouda A. 1. 2011. Analyse des systemes piscicoles dans la vallée du l'Jiger (Nord Bénin) Int. J. Biol. Chem. Sei. 5(5) 12p

[31] Kasamira, F.F., 2007. Etude de la densité de semis du bananier et son impact sur le développement végétatif, cas de KATANA. Inédit UCB, 22pages.

Citation: Mushagalusa Namegabe Janvier, et.al, "Opportunities and Constraints Facing Fish Production System in DR Congo”. International Journal of Innovative Studies in Aquatic Biology and Fisheries, 6(1), pp.18-28. http://dx.doi.org/10.20431/2454-7670.0601003

Copyright: (C) 2020 Authors. This is an open-access article distributed under the terms of the Creative Commons Attribution License, which permits unrestricted use, distribution, and reproduction in any medium, provided the original author and source are credited. 